\title{
Uterine Corpus Carcinoma Pathologic Primary Tumor TNM Finding v7
}

National Cancer Institute

\section{Source}

National Cancer Institute. Uterine Corpus Carcinoma Pathologic Primary Tumor TNM

Finding v7. NCI Thesaurus. Code C89556.

A pathologic finding about one or more characteristics of uterine corpus carcinoma,

following the rules of the TNM AJCC v7 classification system as they pertain to staging of the primary tumor. TNM pathologic primary tumor findings are based on clinical findings supplemented by histopathologic examination of one or more tissue specimens acquired during surgery. 